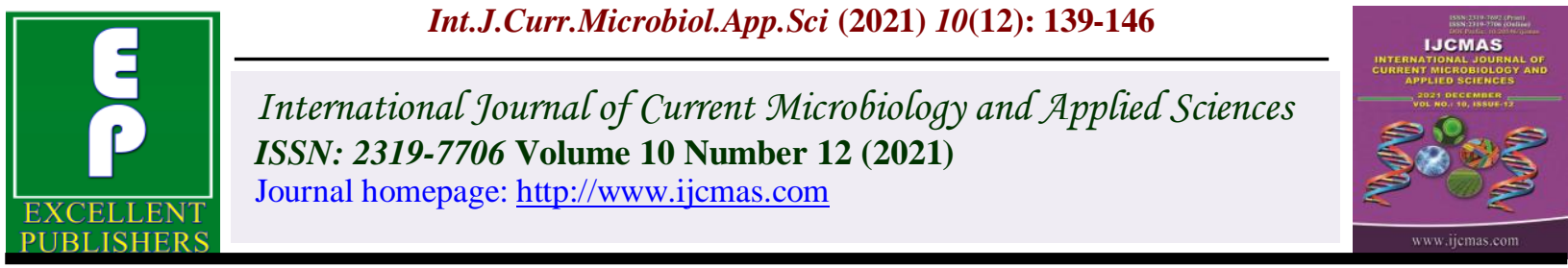

Original Research Article

https://doi.org/10.20546/ijcmas.2021.1012.015

\title{
Phytodiversity of Threatened Ethno Medicinal Plant Species in West Khasihills District of Meghalaya, India
}

\author{
Pynkupbor Jyndiang ${ }^{1 *}$, Eugenia P. Lal ${ }^{2}$, Somnath Sen ${ }^{1}$, Neelam Khare ${ }^{1}$ and \\ Afaq Majid Wani ${ }^{1 *}$ \\ ${ }^{1}$ Department of Forestry, ${ }^{2}$ Department of Biological Sciences, Sam Higginbottom University \\ of Agriculture, Technology and Sciences, Prayaraj-211007, India \\ *Corresponding author
}

Keywords

Phytodiversity,

Threatened,

Medicinal plants,

Shannon-Weiner

diversity index

\section{Article Info}

Received: 05 November 2021 Accepted:

30 November 2021

Available Online:

10 December 2021
A B S T R A C T

The exploration and survey for diversity of threatened of ethno-medicinal plant species in West Khasi Hills District of Meghalaya was conducted during 20202021 for 15 villages in Byrki, Pyndensohphoh, Pyndenmawbah, Marshan, Thangkhmahjah, Nongkhlaw, Nongkynjang, Nonglwai-I, Nonglwai-II, Mawthungkper, Jaidoh, Nongklung Rim, Nongklung, Marskuin and Nongjyllieh. The methodology followed the quantitative analysis and use of phytosociological aspects between the species. Quadrate size $100 \mathrm{~m}^{2}$ for trees, $50 \mathrm{~m}^{2}$ for shrubs and $10 \mathrm{~m}^{2}$ for herbs were used and herbariums were made for every species specimen collected. The result of the present study of 15 villages surveyed recorded 17 species of trees belonging to 11 families, 10 species of shrubs belonging to 8 families and 15 species of herbs belonging to 8 families. In term of Taxonomic status and number of individuals Pinuskesiya was found to be the most maximum tree species, Rubuskhasiana was found to be the most maximum shrub species, while, Fagopyrumdi botrys was found to be the most maximum herb species. On comparison of the result of the phytosociological aspects of 15 villages, it concluded that Nongklung Rim showed the highest values for Shannon-Weiner diversity index $\left(\mathrm{H}^{\prime}\right)(0.58)$ for tree species, Nongjyllieh showed the high value for Shannon-Weiner diversity index $\left(\mathrm{H}^{\prime}\right)$ (0.59) for shrub species, while Pyndensohphoh, Nongkynjang, Nonglwai-I, Nongklung and Nongjyllieh showed the highest value for Shannon-Weiner diversity index $\left(\mathrm{H}^{\prime}\right)(0.57)$ for herb species. These plants would be of much benefit, if evaluated and introduced in the modern scientific health care system. However, the decline in population due to over harvesting and habitat destruction of these plants calls for nursery measures for their effective conservation. 


\section{Introduction}

The state of Meghalaya is blessed with rich natural resources including vast variety of plant species. It constitutes about $18 \%$ of the total flora of the country; of these 3128 and 1237 are flowering and endemic plants species, respectively. However, their distribution and diversity in the state vary depending on the topography of the area, elevation, rainfall, temperature and other environmental factors (Myrchiang et al., 2019).

The Meghalaya state is dominated by the tribal people (Khasi, Pnar and Garo), who are dependent on the forests for their day to day life. The use of wild plants as a source of medicine is a part of the custom and ethnicity of these people. Their deep-rooted culture of using medicinal plants have acquainted them with knowledge of medicinal properties of several plants, which are now used to treat human and livestock ailments, and this knowledge is being transferred from generation to generation. Medicinal plants have played an immense role in supporting the primary healthcare system of the state. About 95\% of traditional medicine preparations are mentioned to be of plant origin, and $90 \%$ of the rural people depend on this system. The collection and processing of these medicinal plants contributes a main part to the economy of the state (Choudhury et al., 2012).

Traditionally, the Khasi, the Garo and the Pnar people, are known to embrace a vast knowledge about intrinsic values of our Mother Nature including the use of plants species for treatment of different diseases for ages.

This kind of knowledge is conveyed orally from one generation to another. Not every individual of the community possesses this knowledge or capability to cure. Rather, knowledge of identification of plants, their collection and uses are limited to a few individuals, commonly known as the local herbal practitioners or 'Nong e DawaiPnar in Pnar and Kabirait' in Khasi language. Such knowledge is getting eroded due to influence of modernization and introduction of alternative methods of cure.

Mining and other anthropogenic activities are further putting pressure on these plants. Some studies on documentation of medicinal plants used in various parts of Meghalaya have been done (Sangma et al., 2017) but considering the rich ethnic diversity and existing traditional knowledge in the state the studies are meagre. Hence, it is urgently required that such existing knowledge be documented and preserved for future generation. With this objective we have collected and documented the information on plants and parts used and method of use to cure various ailments.

\section{Materials and Methods}

\section{Study Area}

The study site is located in Nongstoin of West Khasi Hills District state of Meghalaya which is about $93.6 \mathrm{~km}$ west of shillong the state capital of Meghalaya. Nongstoin is the headquarters of west khasi hills district in the state of Meghalaya in India. West khasi hills district is divided into four blocks Mairang, Mawshynrut, Mawthadraishan and Nongstoin.

Nongstoin belong to the subtropical forests are part of the larger Indo-Burma biological hotspot with many endemic species not found anywhere else in the world. Vegetation of the area can be broadly categorized into tropical forest, subtropical-broad leaved and pine forest, temperate forest and grassland. 15 villages will be selected randomly which are locally characterized and known with higher village forest coverage in Nongstoin region. 


\section{Sampling method}

Based on the objective, the research will be carried out in 15 randomly selected villages of Nongstoin region, West Khasi Hills, Meghalaya. The plant species community study will analyse trees, shrubs and herbs. In each village, quadrates will be laid randomly with different quadrate sampling sizes and in each quadrate sampled the species name and the no. individuals will be recorded. In one village ten of quadrates of $10 \mathrm{~m} \times 10 \mathrm{~m}$ were laid for trees, $5 \mathrm{~m} \times 5 \mathrm{~m}$ for shrubs and $1 \mathrm{mx}$ $1 \mathrm{~m}$ for herbs.

\section{Results and Discussion}

The result of the present study of the 15 villages surveyed at Nongstoin region Private Forest as whole, concluded that an overall occurrence of 17 species of trees belonging to 11 families were recorded which consist a total number of 1463 individuals. While, an overall occurrence of 10 species of shrubs belonging to 8 families recorded a total number of 1826 individuals. Overall occurrence of 15 species of herb belonging to 8 families recorded with a total number of 2343 individuals.

\section{Diversity Indices and other parameters}

All the 15 villages' elevation stand is abundantly dominated by Pinuskesiya Overall, the mid elevation showed the highest IVI parameter of dominant tree species for Pinuskesiya, high elevation stand showed the highest IVI parameter of dominant shrub species for Rubuskhasiana and herbaceous species for Fagopyrumdi botrys.

\section{Part used}

The herbal remedies for different ailments were prepared by using the whole plant either singly or in combination. Plant parts which were used singly include leaves, bark fruits, roots, seeds and stems, and in combination different proportions of the above parts were used. Among the single parts used for tree species were that of leaves (25\%), Stem (12.5 $\%)$, bark (25\%) and fruits (25\%).

For combination parts used seed/root (6.25\%) followed by bark/seed (6.25\%). For shrub species plant parts which were used singly include leaves (30\%), fruits (40\%) and whole plant (10\%). Combination parts used leaves/fruits (10\%), barks /seed (10\%) and for herb species which were used singly include leaves $(53.33 \%)$, bark $(6.66 \%)$, root $(6.66 \%)$ and whole plant (20\%). While, for combination leaves/root (13.33\%). The used of whole plant was mainly for herbaceous species that contributed to $20 \%$ of the total species.

The remedies from these plants were often utilized in the form of extract, juice, paste and powder. Paste made from leaves, fruits, bark, seeds and stem were applied on cuts, wounds, boils and skin diseases. Other preparation included chewing the raw plant and inhaling smoke or vapor generated by burning. Some plants were boiled, while others were applied directly in fresh form or topically.

\section{Ailments treated}

A wide range of ailments were treated using these plants. The majority of the species had multiple therapeutic uses, while few were used for single diseases.

Among the ailments categories, the gastrointestinal and digestive system disorders were treated, external injuries, bites and dermatological problems, head and thermoregulatory and nervous system problem, cancer and musculoskeletal problems and ophthalmological and odological problems were treated. 


\section{Endenmism and threat status}

Out of the total 42 plant species, 7 species were endemic. These endemic medicinal plants were distributed in 7 families. The family Theaceae with 2 species exhibited the highest number of endemics followed by Rosaceae, Elaeagnaceae, Symplocaceae, Pinaceae and Rubiaceae, while other having less than 1 species. Most of the endemic species recorded were trees ( 3 species), shrubs ( 3 species) followed by herbs ( 1 species). Of the total endemic species most found in the wild while both cultivated and wild as well as cultivated. In the present study, out of 42 medicinal plant species, 39 species were found to be under various threat categories. Majority of the threat species were trees, shrubs followed by herbs. Of these, 39 species belonging to 25 families fall under different threat categories at global level. This includes critically lower risk (21 species), least concern ( 5 species), rare (7 species), near threatened (3 species) and data deficient (2 species). One species that were endemic were also near threatened and one of them was trees. There were 5 species that are considered as rare to 15 villages in West Khasi Hills District and also to the state of Meghalaya.

The study of ethno-botany of medicinal plants in 15 different village's information will be taken from with help and consent of tribal and traditional healer. Interviewing the local communities of each village in the form of structure questioning which include local name of the plants, parts use and treatment. The value of the Shanon diversity Index $\left(\mathrm{H}^{\prime}\right)$ in the present study for tree species in 15 villages of West Khasi Hills, Meghalaya was (0.5-0.58), shrubs was (0.6-0.59) and herbs was (0.02-0.57). The species richness index (Dmg) in the present study for tree species in 15 villages of West Khasi Hills, Meghalaya was (1.8-2.42), shrubs were (1.5-1.93) and herbs were (1.39-2.02). The Dominance index value reported in the present study for trees in 15 villages of West Khasi Hills, Meghalaya ranges from (0.2-0.21), for shrubs ranges from $(0.14-0.22)$ and for herbs ranges from (0.2$0.19)$ which corresponds well with the reported range for tropical forest by several local people.

The 15 villages in West Khasi Hills District, Meghalaya in northeast India is rich in medicinal plant diversity. The present analysis clearly reveals that majority of these species are either endemic to the region or falls under various threat categories. The dominance of Fabaceae, Theaceae, Myricaceae, Pinaceae and Rosaceae could be attributed to their wider distribution in the flora of the villages. Of different life forms, the dominance of trees under the threatened category indicates that many plants might have become endangered due to logging as well as shifting cultivation. The dominance of trees, shrubs and herbs as medicinal plants in the area could be attributed to their easy accessibility (Damonmiand Wani (2021).

Wild habitats were found to be major pools but the collection of plant material through destructive harvesting makes them prone to threat and extinction. Also these habitats are subjected to anthropogenic influences and are consequently shrinking in size due to an ever population pressure and over exploitation.

Extreme anthropogenic pressures seem to be the major cause of population decline and availability of the medicinal plants, as evident by the presence of tree species 21 species falls under lower risk, 5 species least concern, 7 species rare, 3 species near threatened and 2 species data deficient that falls under various threat categories. 
Fig.1 Map showing the location of the 15 villages Private Forest in the WestKhasi Hills district of Meghalaya in Northeast India.

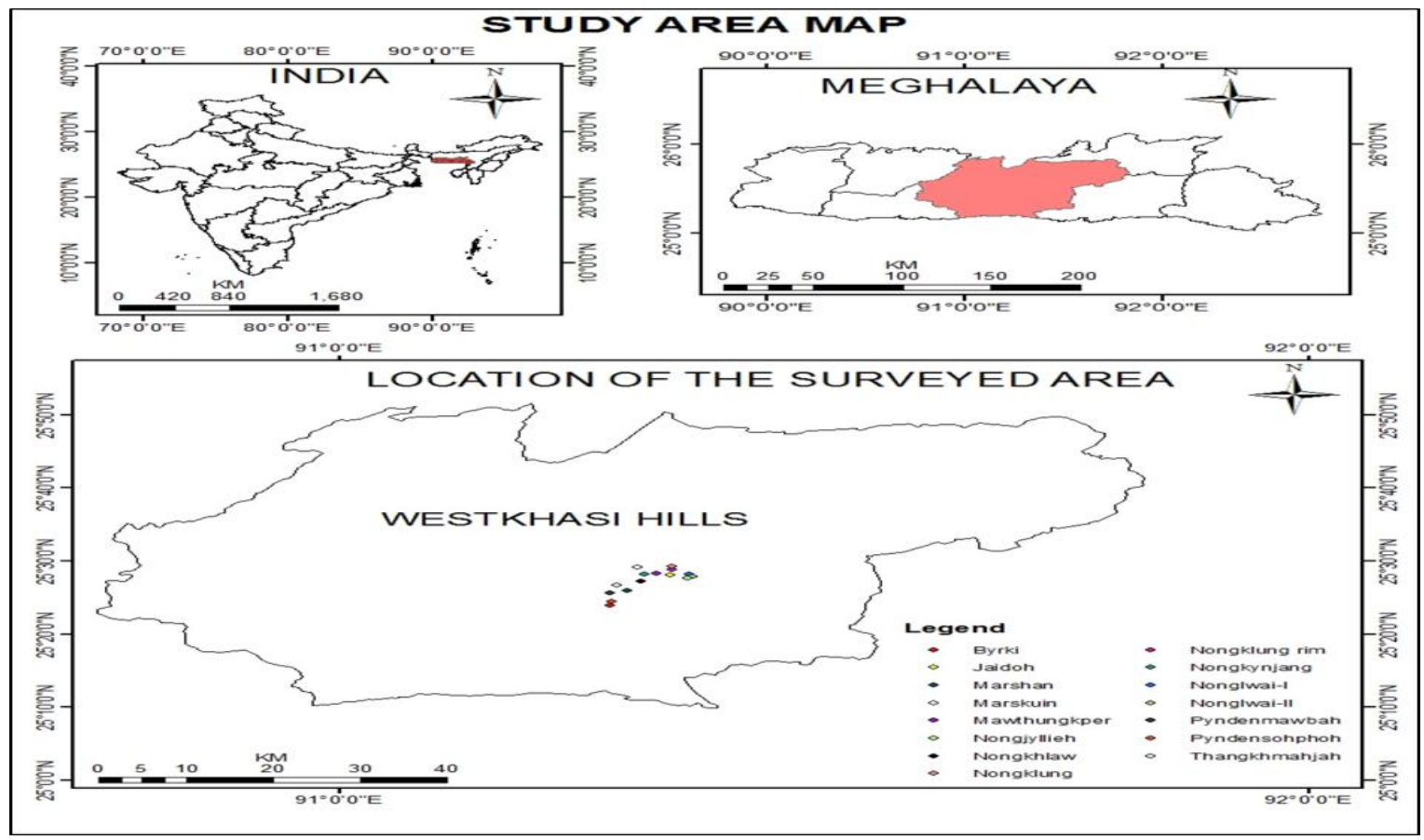

Table.1 Diversity parameters of tree species

\begin{tabular}{|c|c|c|c|c|c|c|c|c|c|c|}
\hline \multirow{2}{*}{ Sl.no } & \multirow{2}{*}{ Name of villages } & \multicolumn{3}{|c|}{$\begin{array}{c}\text { Shannon's } \\
\text { diversity index }\end{array}$} & \multicolumn{3}{c|}{$\begin{array}{c}\text { Species richness } \\
\text { index }\end{array}$} & \multicolumn{2}{c|}{ Dominance index } \\
& & T & S & H & T & S & H & T & S & H \\
\hline $\mathbf{1}$ & Byrki & 0.50 & 0.57 & 0.51 & 1.96 & 1.66 & 1.78 & 0.15 & 0.19 & 0.13 \\
\hline $\mathbf{2}$ & Pyndensohphoh & 0.48 & 0.52 & 0.57 & 2.10 & 1.77 & 1.71 & 0.11 & 0.14 & 0.17 \\
\hline $\mathbf{3}$ & Pyndenmawbah & 0.50 & 0.51 & 0.52 & 1.94 & 1.79 & 1.72 & 0.12 & 0.14 & 0.14 \\
\hline $\mathbf{4}$ & Marshan & 0.54 & 0.57 & 0.54 & 1.90 & 1.42 & 1.55 & 0.15 & 0.17 & 0.15 \\
\hline $\mathbf{5}$ & Thangkhmahjah & 0.5 & 0.54 & 0.02 & 2.20 & 1.93 & 2.02 & 0.14 & 0.19 & 0.04 \\
\hline $\mathbf{6}$ & Nongkhlaw & 0.55 & 0.55 & 0.53 & 1.80 & 1.65 & 1.58 & 0.21 & 0.16 & 0.14 \\
\hline $\mathbf{7}$ & Nongkynjang & 0.53 & 0.57 & 0.57 & 2.00 & 1.44 & 1.52 & 0.15 & 0.16 & 0.17 \\
\hline $\mathbf{8}$ & Nonglwai-I & 0.52 & 0.60 & 0.57 & 1.71 & 1.28 & 1.44 & 0.15 & 0.22 & 0.17 \\
\hline $\mathbf{9}$ & Nonglwai-II & 0.55 & 0.58 & 0.52 & 1.68 & 1.48 & 1.59 & 0.17 & 0.20 & 0.14 \\
\hline $\mathbf{1 0}$ & Mawthungkper & 0.51 & 0.55 & 0.56 & 2.23 & 1.84 & 1.99 & 0.15 & 0.18 & 0.18 \\
\hline $\mathbf{1 1}$ & Jaidoh & 0.54 & 0.56 & 0.56 & 2.42 & 1.63 & 1.77 & 0.18 & 0.20 & 0.19 \\
\hline $\mathbf{1 2}$ & Nongklung Rim & 0.58 & 0.57 & 0.54 & 1.69 & 1.65 & 1.59 & 0.20 & 0.19 & 0.16 \\
\hline $\mathbf{1 3}$ & Nongklung & 0.53 & 0.57 & 0.57 & 1.92 & 1.50 & 1.39 & 0.17 & 0.17 & 0.17 \\
\hline $\mathbf{1 4}$ & Marskuin & 0.52 & 0.58 & 0.56 & 2.18 & 1.63 & 1.84 & 0.16 & 0.26 & 0.18 \\
\hline $\mathbf{1 5}$ & Nongjyllieh & 0.50 & 0.59 & 0.57 & 2.40 & 1.66 & 1.82 & 0.13 & 0.21 & 0.20 \\
\hline
\end{tabular}

T: Trees S:Shrubs H:Herbs 
Fig.2 Major ailment treated by endemic and threatened medicinal plants in West Khasi Hills, Meghalaya.

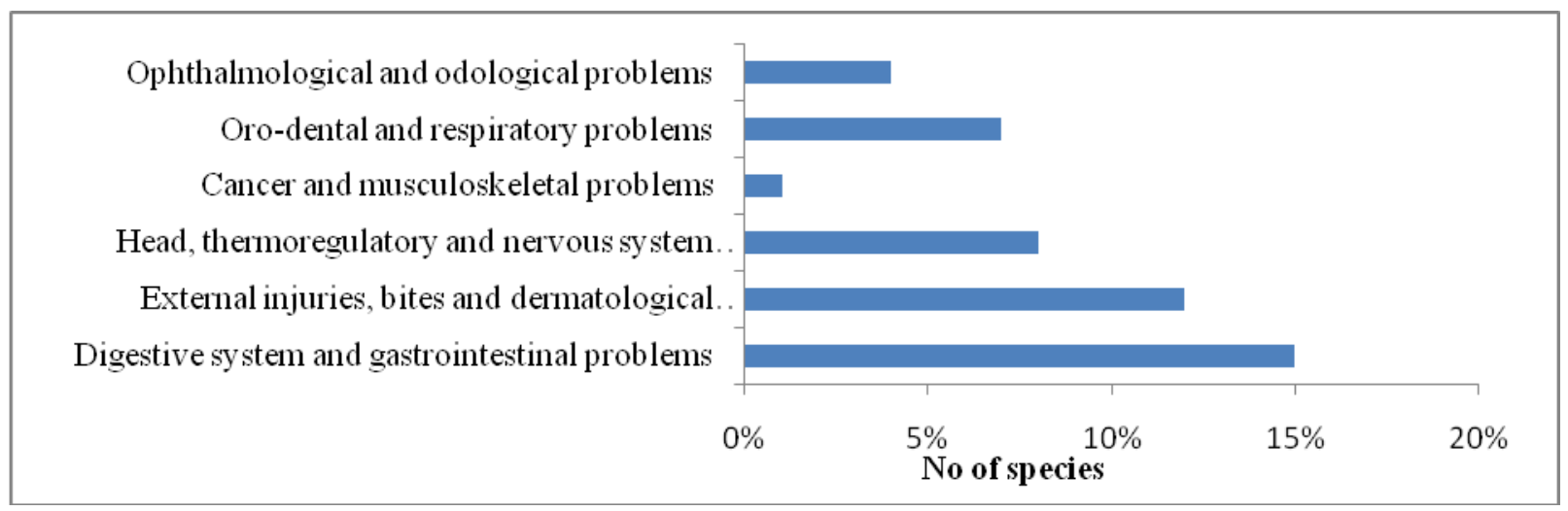

Fig.3 Proportion of plants used singly and in combination
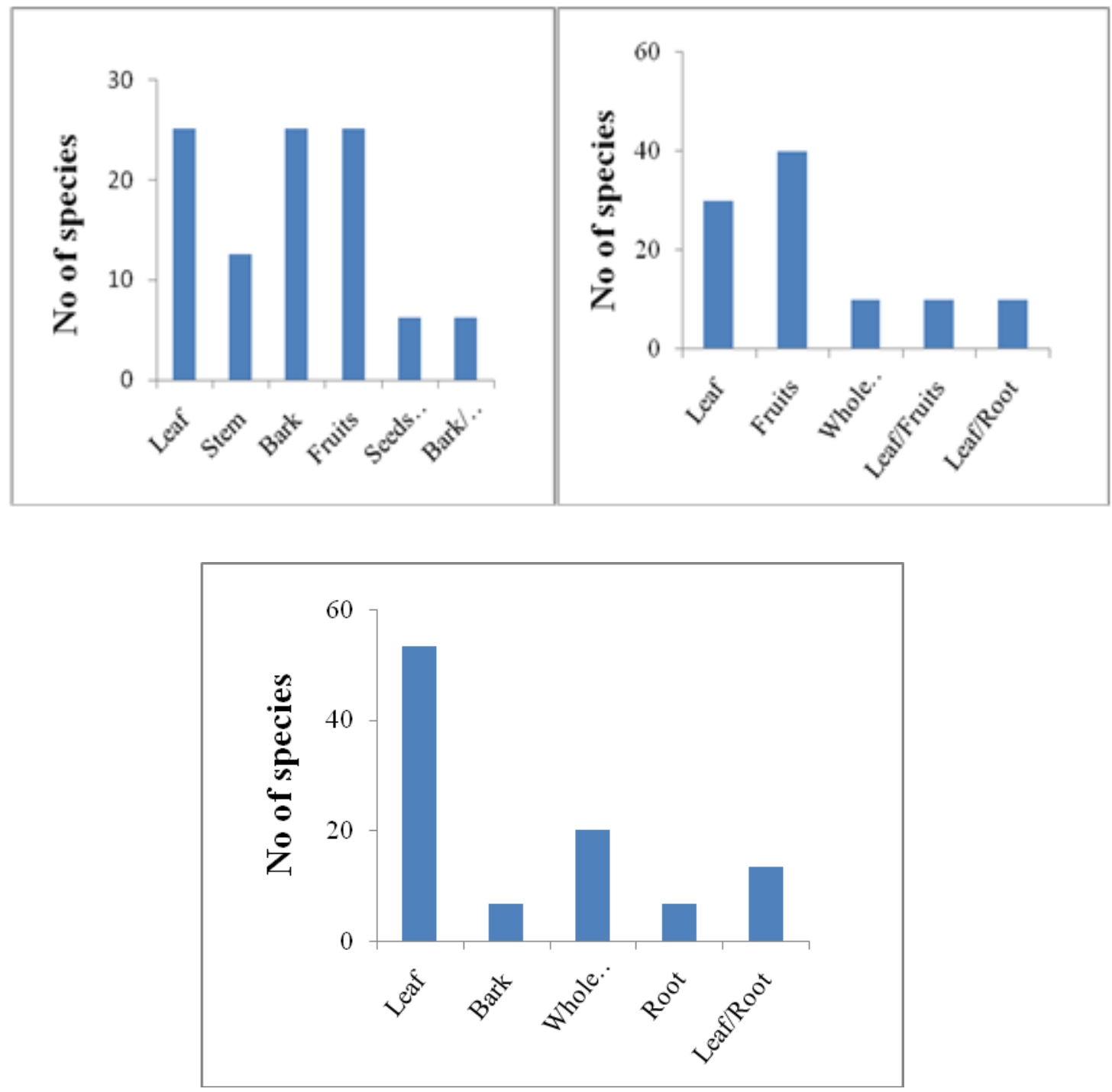
Fig.4 Proportion of medicinal plant species under different threat categories

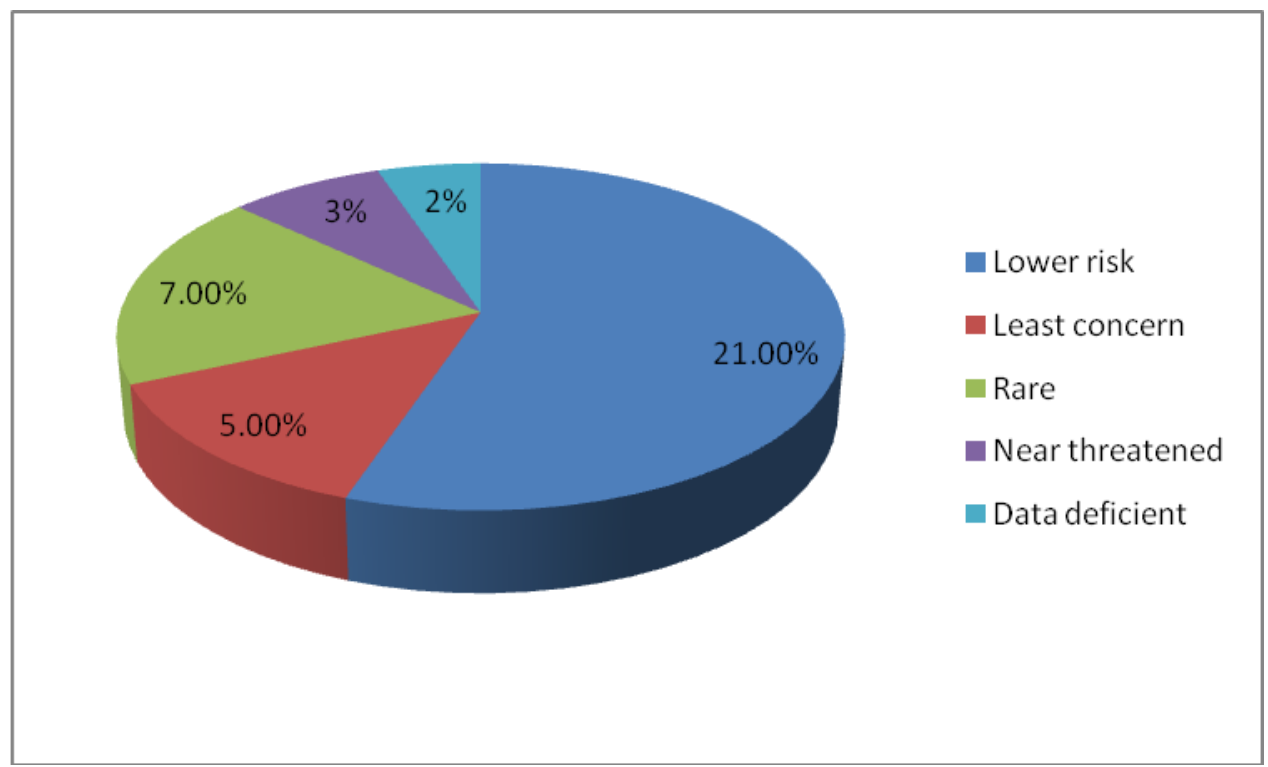

The study revealed that the people of Byrki, Pyndensohphoh, Pyndenmawbah, Thangkhmahjah, Marshan, Nongkhlaw, Nongkynjang, Nonglwai-I, Nonglwai-II, Mawthungkper, Jaidoh, Nongklung Rim, Nongklung, Marskuin and Nongjyllieh villages have rich knowledge of medicinal plants and this private village forest can be concluded as forest of tropical mixed evergreen type with portions of deciduous components.

As a whole the general woody vegetation presents a homogenous appearance mixed with bamboo forest and grassy slopes.

This present research study provides a critical analysis of tree, shrub and herb species richness in 15 different villages located in Nongstoin town of West Khasi Hills District, Meghalaya of the private forest.

In these 15 different villages of the private forest comprised of 17 species of tree, 10 species of shrub and 15 species of herb. However, more than 15 species of tree, 8 species of shrub and 12 species of herb were common in these villages.

\section{Acknowledgement}

Authors are thankful to College of Forestry, Sam Higginbottom University of Agriculture, Technology and Sciences, Prayaraj, India for providing support to carry out the research work. The authors are also thankful to the Headman of 15 different villages in West Khasi Hills District, Meghalaya for providing basic infrastructure and logistic support to carry out the research work. The constructive criticism of manuscript by anonymous reviewers is gratefully acknowledged. The help of local administration and people during the field survey is highly appreciated.

\section{References}

Sajem, A. and K. Gosai (2006). Traditional use of medicinal plants by the Jaintia tribes in North Cachar Hills district of Assam, Northeast India, Journal of ethnobiology and ethnomedicine 2 (1), 1-7.

Mir, A. H., K. Upadahaya and H. Choudhury (2014). Diversity of Endemic and Threatened Ethnomedicinal Plant Species in Meghalaya, North-East India, International Research Journal Environmental science 3 (12), 64-78

Barbhuiya, A. R., G. D. Sharma and A. 
Arunachalam (2009). Diversity and conservation of medicinal plants in Barak valley, Northeast India, CSIR.

Singh, B., S. K. Borthakur and S. J. Phukan (2014). A survey of ethnomedicinal plants utilized by the indigenous people of Garo Hills with special reference to the Nokrek Biosphere Reserve Meghalaya, India, Journal of herbs, species \& medicinal plants 20 (1), 130.

Laloo, D. and S. Hemalatha (2011). Ethno medicinal plants used for diarrhea by the tribals of Meghalaya, Northeast India, Pharmacognosy reviews.

Damonmi E. Dkhar and AfaqMajidWani(2021). Assessment of Plant Biodiversity at 3 Different Elevation of Protected Forest of Subtropical Pine Forest of Meghalaya International Journal of Current Microbiology and Applied Sciences.10(11)

Myrchiang, F., R. E. Lamare and O. P. Singh (2018). Ethno-medicinal plants in Nongtalang, Meghalaya: Their uses and Threats, ENVIS.

Joshi, G. C. and P. Kumari (2012). Biodiversity status, distribution and use pattern of some ethno-medicinal plants, International Journal of conservation 3 (4).

Haridasan, K. and R. R. Rao (1985). Forest flora of Meghalaya. Bishen Singh Mahendra Pal Singh, Dehradun. (1-2).

Haridasan, K., N. J. Lakadong and S. K. Barik (2010). Medicinal plant resources of Meghalaya: Endemism, threat status and consumption pattern.

Singh, M. K., D. K. Meena and K. A. Bharati (2017).Study of forest base ethno-medicinal plants among the forest fringe villages of Balpakram National Park, Meghalaya, Annals of Horticulture 10 (2), 128-137.

Hill, M. O. (1973). Diversity and evenness: A unifying notation and its consequences.
Ecology, 54 (2), 427-437.

Bhuyan, P., M. L. Khan and R. S. Tripathi (2003). Tree diversity and population structure in undistributed and human- impacted stands of tropical wet evergreen forest in Arunachal Pradesh, Eastern Himalayas, India, Biodiversity and Conservation 12: 1753-1773.

Whittaker, R. H. (1965). Dominance and Diversity in land plant communities; Science 147 250260.

Whittaker, R. H., (1969). Evolution of diversity in plant communities; Brook Haven Symp. Biol. 22 178-196.

Maikhuri, R. K. and A. K. Gangwar (1993). Ethnobiological notes on the Khasi and Garo tribes of Meghalaya, Northeast India, Economic Botany.

Choudhury, S. and D. Roy (2012). Prioritisation of biodiversity rich sites in the state of Meghalaya.

Ifo, S. A. and J. M. Moutsambote (2016). Trees species Diversity, Richness and Similarity in Intact and Degraded Forest in the Tropical Rainforest of the Congo Basin: Case of the Forest of Likouala in the Republic of Congo, International Journal of Forestry Research Volume 2016, Article ID 7593681, 12 pages.

Jain, S. K. and R. R. Rao (1997). A Hand Book of Field and Herbarium Methods, Today and Tomorrow Prints and Publishers, New Delhi.

Sangma, T. and U. K Sahoo (2017).Utilization pattern of medicinal plants by different tribes of Garo Hills of Meghalaya, Northeast India.

Jaiswal, V. (2010). Cultural and ethnobotany of Jaintia tribal community of Meghalaya, Northeast India, CSIR.

Kumar, V. and B. S. Desai (2016). Biodiversity and Phytosociological analysis of plant around the Chikhali taluka, Navsari District Gujarat, India.

\section{How to cite this article:}

Pynkupbor Jyndiang, Eugenia P. Lal, Somnath Sen, Neelam Khare and Afaq Majid Wani. 2021. Phytodiversity of Threatened Ethno Medicinal Plant Species in West Khasihills District of Meghalaya. Int.J.Curr.Microbiol.App.Sci. 10(12): 139-146.

doi: https://doi.org/10.20546/ijcmas.2021.1012.015 